IZA DP No. 7949

How School Principals Influence Student Learning

Elizabeth Dhuey

Justin Smith

February 2014

Forschungsinstitut zur Zukunft der Arbeit Institute for the Study of Labor 


\title{
How School Principals Influence Student Learning
}

\author{
Elizabeth Dhuey \\ CIRHR, University of Toronto \\ and IZA \\ Justin Smith \\ Wilfrid Laurier University
}

\section{Discussion Paper No. 7949 \\ February 2014}

\author{
IZA \\ P.O. Box 7240 \\ 53072 Bonn \\ Germany \\ Phone: +49-228-3894-0 \\ Fax: +49-228-3894-180 \\ E-mail: iza@iza.org
}

Any opinions expressed here are those of the author(s) and not those of IZA. Research published in this series may include views on policy, but the institute itself takes no institutional policy positions. The IZA research network is committed to the IZA Guiding Principles of Research Integrity.

The Institute for the Study of Labor (IZA) in Bonn is a local and virtual international research center and a place of communication between science, politics and business. IZA is an independent nonprofit organization supported by Deutsche Post Foundation. The center is associated with the University of Bonn and offers a stimulating research environment through its international network, workshops and conferences, data service, project support, research visits and doctoral program. IZA engages in (i) original and internationally competitive research in all fields of labor economics, (ii) development of policy concepts, and (iii) dissemination of research results and concepts to the interested public.

IZA Discussion Papers often represent preliminary work and are circulated to encourage discussion. Citation of such a paper should account for its provisional character. A revised version may be available directly from the author. 
IZA Discussion Paper No. 7949

February 2014

\section{ABSTRACT}

\section{How School Principals Influence Student Learning}

Many studies examine the importance of teachers in students' learning, but few exist on the contribution of principals. We measure the effect of principals on gains in primary test scores in North Carolina and estimate the standard deviation of principals' value added to be 0.12 0.17 . We find that the match between principals and schools accounts for a significant amount of principals' value added and also find that replacing the current principal has little effect on non-test score school inputs and outcomes regardless of the new principal's value added, but that brand new principals have a detrimental effect.

JEL Classification: $\quad 121$

Keywords: economics of education, principals, school leadership

Corresponding author:

Elizabeth Dhuey

Centre for Industrial Relations and Human Resources

Department of Management

University of Toronto

121 St. George Street

Toronto, ON M5S 2E8

Canada

E-mail: elizabeth.dhuey@utoronto.ca 


\section{Introduction}

The summer of 2008 saw widespread media coverage of controversial Washington D.C. Schools Chancellor Michelle Rhee and her move to fire roughly 40 school principals in her district. Many of the schools in question were failing to meet the academic proficiency standards of the No Child Left Behind Act, and this change in school leadership was meant to help these struggling schools improve their performance. Not only does this move highlight the value that school districts place on quality leadership within a school, it also demonstrates an underlying belief that principals have an effect on student achievement within their schools.

As managers, principals are responsible for the overall functioning of their school. They direct and supervise the development, delivery, assessment, and improvement of the education of all students in their school. Principals supervise teachers, evaluate their performance, assign them to classrooms, create teaching schedules, and make recommendations to the district about hiring or dismissal (or perform that action themselves). They interact directly with students by monitoring their conduct and by disciplining students who are, for example, frequently truant or disruptive. They also act as liaison between school districts and the school itself, implementing policies passed down by state or district authorities, then communicating feedback on the success of those initiatives. However, despite the importance of these functions in contributing to the educational experience, much of the economics research to this point has focused on teacher quality rather than principal quality.

One of the primary goals of this paper is to measure principal quality by estimating each principal's value added to student achievement with data on North Carolina students between the third and eighth grades. We find that principal value added, estimated with a fixed effect for each principal in a value-added model, has a standard deviation across principals of approximately 
0.17 in math and 0.12 in reading. Extending the model to allow a principal's effect to include a component that is fixed across schools and a component that varies across principal-school matches, we find that the standard deviation of the fixed component shrinks to 0.04 in math and to 0.02 in reading and that the standard deviation of the match-specific component is 0.07 in math and 0.04 in reading.

Having established that there is significant variation across principals in their value added, our second main goal is to determine why some principals are better than others at adding value to student scores. We tackle this question in two ways. First, we regress our estimated principal fixed effects on a set of indicators for the level and quality of each principal's prior education. The results show that having an advanced degree increases value added in reading and having a non-competitive doctorate degree increases value added in math. Second, we assess the effects of the arrival of a new principal at the school on various school-level variables, the idea being that high value added principals might generate good student academic outcomes because they influence one or more of a variety of related school inputs or outcomes. More specifically, we estimate what happens when the incoming principal's value added is similar to, higher than, or lower than that of the outgoing principal, or whether the incoming principal has no experience at all as a principal in North Carolina. We find that incoming principals with no prior experience reduce the fraction of students who attend school daily, and the fraction of teachers with more than 11 years' experience, and they increase levels of teacher turnover and the percentage of teachers with zero to three years' experience. Other significant results are that replacing the current principal with one of lower value added immediately decreases long-term suspensions.

All of this evidence suggests that a single school looking to improve student academic achievement could simply hire a high-quality principal, or at the very least avoid low-quality 
principals or those who have no prior experience as a principal. It is unclear, however, what effect this would have on student achievement on a broader scale, since a high-quality principal who moves to a new school necessarily is replaced by an existing or new principal who may not be of similar quality, which could lead to a fall in achievement in the old school. Thus, the potential benefits of reallocating principals between schools are best seen as equalizing the distribution of achievement rather than as a tide that lifts all boats.

\section{Existing Literature on the Effect of Principals}

Compared to the large, well-established literature on teacher quality, there exists a relatively small quantitative literature on principals. ${ }^{1}$ Recent evidence finds that

- principals who dedicate more time to organizational management lead schools with higher state-assigned grades (Horng, Klasik, and Loeb 2009);

- experienced principals import their policies and practices from one school to another (Cannon, Figlio, and Sass 2012);

- self-assessment of principals' organizational management skills predicts growth in stateassigned school grades (Grissom and Loeb, forthcoming); and

- principals are motivated by the opportunity to change schools (Cullen and Mazzeo 2007).

In addition, there is a small literature on principal turnover and mobility. Beteille, Kalogrides, and Loeb (2012) find that turnover is detrimental to school performance, whereas Miller (2013) finds that, in North Carolina, turnover does not have a large effect on school

\footnotetext{
${ }^{1}$ See Hanushek (2006) for a review of the teacher quality literature, and Hallinger and Heck (1998) for a review of the qualitative principal literature.
} 
performance, but it does decrease teacher retention. ${ }^{2} \mathrm{Li}$ (2011), using a small sample of principals from the same state, finds that incentives created by No Child Left Behind decrease average principal quality at schools serving disadvantaged students.

A small and more recent literature exists using student achievement data to try to directly measure the value-added of school principals in a variety of ways. Dhuey and Smith (2013) estimate fixed effects for principals in the Canadian province of British Columbia and find substantial variation among principals in value added in both math and reading. They estimate that a one standard deviation improvement in principal quality can boost student performance between grade four and seven by $0.289-0.408$ standard deviations in reading in math. The current manuscript expands on this working paper in many ways. Most importantly, in this paper we are able to calculate a yearly value-added measure versus a value-added measure of the grade seven principal from test score gains from grade four to grade seven. We are also able to extend the basic model to allow for "match effects," where part of the principal effect is portable across schools and part depends on the school where they work. We then are also able to relate the fixed

\footnotetext{
${ }^{2}$ While our analysis and that of Miller (2013) use a similar sample of data drawn from the same source, our analyses are fundamentally very different. Our manuscript focuses first on estimating principal value added, and subsequently on determining what makes higher value added principals better at raising student achievement. Miller (2013) focuses on the dynamics of student achievement surrounding principal transitions, and explanations for this phenomenon. Like Miller (2013), the second part of our analysis examines school outcomes following principal transitions, but the underlying goal is different. We examine transitions to differentiate the effects on school outcomes of principals of different quality, whereas Miller (2013) estimates the overall effect of changing the principal.
} 
characteristics of principals — such as education level and quality of educational institution — to quality. Finally, we can calculate how new principals of differing quality change aspects of the educational process after they enter a school.

Grissom, Kalogrides, and Loeb (2012) calculate a few variations of principal-value-added models being proposed by various state and districts to be used to link to principal value-added to merit pay. They compare and contrast the results to each other and to non-test-based assessments of principal quality. They find that, among the models they estimate, that models that attribute all the school effect to the principal are most highly correlated with non-test-based measures of principal quality. ${ }^{3}$ Most importantly, in contrast, our model, which Grissom, Kalogrides, and Loeb do not estimate, disentangles principal effects from school fixed effects, which is important because it is necessary to disentangle the effect of the school quality from principal quality.

Coelli and Green (2012) estimate the lower bound of the variance of principal effects on graduation probabilities and grade 12 provincial final exam scores in British Columbia. In particular, they find that getting a principal who is one standard deviation better will increase graduation rates and English exam scores by approximately 2.5 percentage points. In addition, a recent working paper by Branch, Hanushek, and Rivkin (2012) use data from Texas to estimate the importance of principals on student math and reading test score gains in two ways. First, they estimate principal-by-school fixed effects using a model that related student achievement as a function of prior achievement as well as student and school characteristics. They find that the

\footnotetext{
${ }^{3}$ Chiang, Lipscomb, and Gill (2012) also examine using school fixed effects to predict principal quality and find that school value-added data do not provide information useful for evaluating principals.
} 
overall standard deviation of the principal effectiveness is 0.207 . The also include a model with school fixed-effects in which they identify principal effectiveness based on within-school achievement differences and find that with this selected sample the standard deviation decreases. Second, they directly estimate a lower bound variance using a method similar to Coelli and Green (2012). ${ }^{4}$

Our empirical strategy is similar to the previous literature only in the sense that we are using student-level administrative achievement data to calculate a value-added model of principal effectiveness. Overall, our paper contains many novel contributions. First, and most importantly, we separate the independent influences of principals and school from each other. This is a vital contribution to this literature as fixed characteristics of schools can affect principal sorting across schools and can also affect student value added in ways that are not influenced by principals. Therefore, without controlling for school fixed effects, estimates of principal value added cannot be disentangled from sorting and unobserved factors. In addition, we extend the model to allow principal value added to depend on the match with the school. All previous analysis thus far provides estimates of principal effects that are fixed across schools. It is entirely plausible, however, that a principal's effectiveness varies from one school to another. Therefore, it is important to estimate the influence these match effects have on principal fixed effects. Finally, with estimates of principal value added in hand, we explain what drives differences across principals in this measure. To do so, we first estimate the relationship between principal

\footnotetext{
${ }^{4}$ In a working paper, Clark, Martorell, and Rockoff (2009) use data from New York City to estimate how the characteristics of principals are correlated to school performance and other measures. Similarly to this paper, they find little evidence that there is a strong relationship between principal education levels and school performance.
} 
fixed effects and their prior education. Second, by observing what happens after schools change principals, we examine whether principal value added is driven by a principal's ability to influence non-test-score related factors at the school level.

\section{Principals in North Carolina}

Many of the guidelines and procedures regarding principals in the North Carolina are governed by the North Carolina General Statutes, Chapter 115C Article 19. These laws provide rules regarding the hiring and firing of principals and lists the requirements for an individual to qualify as a school administrator, which includes passing an exam adopted by the State Board along with having a graduate degree or equivalent.

In North Carolina, to be hired, a principal must be appointed by the school district's board of education based on the recommendation of the district's superintendent. Vacancies typically are posted on a statewide system, and candidates are screened by an interview team of district administrators, teachers, staff, and parents, which then recommends finalists to the superintendent (Miller 2013). Initial employment contracts are for two to four years and may be renewed for four-year intervals after the end of the first contract. Once hired, principals are evaluated annually by either the superintendent or the superintendent's designee. After three years, principals are eligible for status as career administrators, which protects them from being dismissed without cause. Principals who previously had been teachers retain that career status if they are not offered a new contract. Salaries are set by a statewide schedule that is a function of experience, education, and school size; school districts may provide additional salary, which usually accounts for approximately 10 percent of total pay (Li 2011). 
Under North Carolina statutes, principals possess twelve powers and duties: (1) grading and classifying pupils; (2) making accurate reports to the superintendent and the local board; (3) improving instruction and community spirit; (4) conducting fire drills; (5) disciplining students; (6) protecting school property; (7) reporting certain acts to law enforcement and the superintendent; (8) making available school budgets and school improvement plans; (9) evaluating licensed employees and developing mandatory improvement plans; (10) transferring student records; (11) signing driving eligibility certifications; and (12) establishing school improvement teams. ${ }^{5}$

\section{Empirical Specifications}

\section{A. Estimating Principal Effects}

To estimate the principal effects, we use the following value-added model of students' test scores:

$$
y_{i t}=\beta_{0}+y_{i t-1} \beta_{1}+x_{i t}^{\prime} \beta_{2}+z_{s(i, t) t}^{\prime} \beta_{3}+\dot{p}_{p(i, t) t}^{\prime} \beta_{4}+\delta_{p(i, t)}+\varphi_{s(i, t)}+\eta_{t}+\varepsilon_{i i t}
$$

where $\boldsymbol{y}_{i t}$ is the math or reading score for student $i$ at time $t ; y_{i t-1}$ is the student's one-year lagged math or reading score; $\boldsymbol{x}_{i t}^{\prime}$ is a vector of student-level demographic characteristics; $z_{s(i, t) t}^{\prime}$ is a vector of school-level demographic characteristics for the school that student $i$ attends at time $t$; $p_{p(i, t) t}^{\prime}$ is a vector of principal-level, time-changing characteristics for student $i$ 's principal at time

\footnotetext{
${ }^{5}$ While principals possess the power of evaluating teachers, the superintendent or the board of directors (for regional schools) have the power to employ and contract with teachers along with the duty to maintain personnel files and participate in the firing and demoting.
} 
$t ; \delta_{p(i, t)}, \varphi_{s(i, t)}$, and $\eta_{t}$ are time-invariant principal, school, and year effects; and $\varepsilon_{i t}$ is an idiosyncratic error term. ${ }^{6}$

We treat principal effects as parameters and estimate them using ordinary least squares (OLS) in a fixed-effects model. Our preferred model includes school fixed effects because without them, estimated principal effects will conflate differences between principals and differences between schools. Since the fixed characteristics of schools might affect principal sorting or affect student value added in ways that are not influenced by principals, they should be controlled for to estimate a principal effect unaffected by sorting and unobserved factors.

There is one key practical difficulty that arises when estimating principal effects and school effects jointly via OLS. Principals and schools become grouped with one another through principals' employment at a common set of schools as they move between schools over time. ${ }^{7} \mathrm{~A}$ model containing a fixed effect for all principals and all schools is overparameterized because there are collinearities between principal and school dummies within these groups. More specifically, the sum of the principal dummies equals the sum of the school dummies inside each group. This is a slightly more complicated version of the typical dummy variable trap.

\footnotetext{
${ }^{6}$ The value added estimates provided in this paper are conditional on the effect of the school principal on initial test scores in grade 3. A high quality elementary school principal may raise grade 3 test scores but then produce smaller value added gains from grade 4 through 8 . This principal could be identified as below average in these estimates but may be raising achievement throughout elementary school by more than other principals identified as above average. ${ }^{7}$ For example, suppose principals A and B have worked at school 1 and principal C has worked at school 2 and none of the principals have ever worked at any other school. Principals A and B and school 1 form one connected group, and principal C and school 2 form another.
} 
Restrictions are therefore necessary to identify principal effects. We follow Mihaly et. al. (2010) and restrict the mean of the principal effects within each group to equal zero. With this restriction, the principal effects are interpreted as deviations from the mean principal in the group. ${ }^{8}$ Occasionally a connected group consists of one school and one principal, in which case we cannot identify that principal's effect. Fortunately, out of 4,415 total principals we can identify fixed effects for 4,289 (97 percent).

Because it would be impractical to report all of the individual principal effects, in the tables below we report several summary measures of the empirical distribution of the principal effects, including the standard deviation, various percentiles, and the difference between the $75^{\text {th }}$ percentile and the median. Our main focus is on the standard deviation. It is possible, however, that our estimates of the standard deviation of the principal effects are upwardly biased due to sampling error — even in the absence of any real principal effect, we still might observe variations in the estimated effect due to random differences between samples of students. Such sampling variation is a problem particularly when a principal fixed effect is based on a small number of students, but as we estimate our principal effects over very large groups of students, sampling error plays a very minor role. Nevertheless, to correct for it, we first estimate the variance of the sampling error using the square of the average of the standard errors of the principal fixed effects, and subtract this estimate from the variance of the principal effects. As in Jacob and Lefgren (2005) and Aaronson, Barrow, and Sander (2007), if the true principal effect is distributed as $\delta_{p} \sim N\left(0, \sigma_{\delta}^{2}\right)$, then conditional on observing a "noisy" estimate of the principal

\footnotetext{
${ }^{8}$ Another option is to simply drop one principal within each group. This is not appropriate in our case because principal effects would then be interpreted as deviations from the left out principal, which depends on which principal is left out.
} 
effect, $\hat{\delta}_{p}=\delta_{p}+v_{p}$, and assuming that $\delta_{p}$ and the error $v_{p}$ are independent, we compute the variance of the true principal effect as $\sigma_{\delta}^{2}=\sigma_{\widehat{\delta}}^{2}-\sigma_{v}^{2}$, where $\sigma_{v}^{2}$ is estimated by taking the average of the square of the standard errors of the principal fixed effects. We also check the robustness of our methods to others in the literature. ${ }^{9}$

\section{B. What Drives Principal Value Added?}

\section{B.1 Principal Value Added and Education Level}

As a first step toward determining why some principals have higher value added than others, we relate our estimated fixed effects to the level and quality of principals’ education. We estimate the following specification by OLS:

$$
\begin{aligned}
& \delta_{p}=\varphi_{0}+\operatorname{CompBA}_{p} \varphi_{1}+\operatorname{CompMA}_{p} \varphi_{2}+\operatorname{PhD}{ }_{p} \varphi_{3}+\operatorname{CompPhD}_{p} \varphi_{4 p} . \\
& +A d v_{p} \varphi_{5}+\operatorname{CompAd}_{p} \varphi_{6}+\zeta
\end{aligned}
$$

The education variables, $\operatorname{CompBA}_{p}, \operatorname{CompMA}_{p}, \operatorname{CompPhD}_{p}$, CompAdv $v_{p}$ are indicator variables for whether the principal has a bachelor’s, master’s, doctorate, or advanced degree from a competitive institution. $P h D_{p}$ and $A d v_{p}$ are indicator variables for whether the principals has a doctorate or advanced degree from a non-competitive institution. We assigned each principal's institution a competitive ranking based on information from Barron's Profiles of

\footnotetext{
${ }^{9}$ In particular, Rothstein (2010) uses a method similar to ours but weights the average of the standard errors; Rockoff (2004) makes assumptions about the distribution of the underlying true principal effects and estimates the variance using maximum likelihood.
} 
American Colleges, 25th ed. ${ }^{10}$ As the dependent variable, we use the estimates of the principal fixed effects. This regression is meant to be descriptive only, so we attach no causal interpretation to the coefficients.

\section{B.2 Principal Value Added and School Level Inputs and Outcomes}

We also measure the effect on various school inputs and outcomes of a change in principals. We estimate specifications of the following form:

$$
O_{s t}=\alpha_{0}+d_{s t}^{\text {rise }} \alpha_{1}+d_{s t}^{\text {fall }} \alpha_{2}+d_{s t}^{\text {same }} \alpha_{3}+d_{s t}^{\text {new }} \alpha_{4}+O_{s t-1} \alpha_{5}+z_{s t}^{\prime} \alpha_{6}+\theta_{s}+\lambda_{t}+v_{i t} .
$$

The independent variables of interest are a set of four dummies indicating the type of principal change a school experiences. The variable $d_{s t}^{\text {rise }}$ equals 1 when the school receives a new principal who has higher value-added than the departing principal. Similarly, $d_{s t}^{\text {fall }}$ equals 1 when the incoming principal's value added is lower than that of the outgoing principal, and $d_{s t}^{s a m e}$ equals 1 when the value added by both the incoming and outgoing principals is similar. Finally, $d_{s t}^{\text {new }}$ equals 1 when the incoming principal is not previously observed in the data. Differences in value added between the incoming and outgoing principals are assigned to rise, fall, or stay the same based on terciles of the difference in principal value added from an Empirical Bayes shrinkage estimate among all principal switches in year $t .{ }^{11}$

\footnotetext{
${ }^{10}$ The indicator equals 1 if the school received a competitive or higher ranking and 0 otherwise.

${ }^{11}$ The Empirical Bayes shrinkage estimate $\hat{\delta}_{p}^{*}$ of the principal effect would shrink our existing estimates based on a signal to total variance ratio:
} 
Prior to estimating equation (3), we estimate the value added of principals with equation (1), using the previous five years of data up to year $t-1$. For example, if school A changes principals in 2004, we measure the difference in value added between the incoming and outgoing principals using data from 1998 to 2003 for both principals. ${ }^{12}$ This method excludes current and future test-score data in creating the value-added measure to avoid introducing simultaneity between school outcomes and the indicator variables on the right-hand side of the equation. As controls in equation (3), we include a set of school-level variables $\left(z_{s t}^{\prime}\right)$ and school fixed effects $\left(\theta_{s}\right)$ to account for other factors that might be correlated with the movement of principals and school outcomes. In robustness checks, we also estimate specifications with school-specific linear time trends to account for any changes over time in outcomes that might be specific to a school.

With these regressions, we can estimate whether schools that change principals have different outcomes than schools that do not, and whether such differences in outcomes vary with principal quality, as measured by previously determined test-based value-added measures. Our school outcomes contain mainly non-test-score-based variables, so in many of our regressions we estimate whether increases or decreases in the ability of the principal to produce test-score $\hat{\delta}_{p}^{*}=\left(\frac{\sigma_{\delta}^{2}}{\sigma_{\delta}^{2}+\sigma_{v}^{2}}\right) \hat{\delta}_{p}$ where the variances are defined in footnote 4 . If our estimate $\hat{\delta}_{p}$ contains mostly noise, then the estimates shrink toward zero. We compute the shrinkage estimate by using our estimates of $\sigma_{\delta}^{2}$ and $\sigma_{v}^{2}$ described previously.

${ }^{12}$ We need to use a constant prior time period so that the principal effects are comparable across time. 
gains can affect other school inputs and outcomes. As the specification is written above, the coefficients on the dummies measure the immediate effect of a change of principal during the first year. We also estimate regressions with dummies that allow the effect to occur in the two additional years following the year the principal changed. This allows the effect of principal switches to occur more gradually over time.

As school inputs and outcomes, we use the following measures: ${ }^{13}$

- the percentage of Adequate Yearly Progress (AYP) targets met;

- the number of crimes per one hundred students;

- the number of long-term suspensions;

- the percentage of students who attend daily;

- $\quad$ the percentage of teachers with advanced degrees in $t+1$;

- the teacher turnover rate between $t$ and $t+1$;

- the percentage of licensed teachers in the school in $t+1$;

- the percentage of National Board Certified teachers in the school in $t+1$;

- the percentage of classes with highly qualified teachers;

- the percentage of teachers in the school with between zero and three years' experience in $t+1$;

- the percentage of teachers with between four and ten years' experience in $t+1$; and

- $\quad$ the percentage of teachers with eleven or more years of experience in $t+1$.

\section{Data and Analysis Sample}

${ }^{13}$ The teacher measures come from $t+1$ to avoid picking up the spurious effect of concurrently moving teachers and principals, since we are interested in changes in these variables that occur after the new principal arrives. 


\section{A. Data Sources}

The primary data for our analysis come from administrative records of the North Carolina Department of Public Instruction, maintained and distributed by the North Carolina Education Research Data Center, for all public schools in the state for the 1998/99-2009/10 school years. The data include a multitude of information on students, teachers, schools, districts, classrooms, and, most important for this research, principals. Moreover, the data include identifiers for principals, teachers, and students that permit us to establish statewide linkages over time. We supplemented this information with data from the 2000 and 2010 censuses, identified by the zip code of each school. ${ }^{14}$

\section{B. Regression Sample}

Because we use the value-added model in test scores to estimate principal quality, we restrict our focus to students with valid math or reading scores in year $t$ and valid math or reading scores in year $t-1$. In the 1996/97 school year, North Carolina passed the ABCs of Public Education, accountability legislation requiring all students in grades three through eight to write standardized tests in math and reading at the end of each school year; we use these standardized tests as our reading and math scores. We observed 5,407,020 student-years between grades four and eight between the 1998/99 and 2009/10 school years with valid test scores in both year $t$ and year $t-1$. We dropped 9,724 observations of students who attended schools with fewer than ten

\footnotetext{
14 The process for attaching the census data to school records is described in detail in a data appendix available from the authors upon request.
} 
students, 491 observations of students who were too far ahead or behind in school for their age, and 8,262 observations we were unable to link to a particular school. Our final analysis sample thus consists of 5,388,543 student-year observations. ${ }^{15}$

\section{Descriptive Statistics}

Table 1 presents summary statistics of test scores and student demographics based on the analysis sample. The math and reading test scores for grades three through eight are standardized to have a mean of zero and standard deviation of 1 for each grade and year. The means of these test scores are slightly positive in our analysis sample, which indicates that the students who were excluded from the sample scored marginally worse than those who were included. About 29 percent of the sample is black, 5 percent Hispanic, and another 5 percent “other race.” In addition, about 9 percent of the sample is in special education, 14 percent are gifted, and approximately 6 percent is learning disabled in either math or reading.

Table 2 shows descriptive statistics for schools, school neighborhoods, and principals in the analysis sample. Of the 1,954 schools that contributed to the sample over time, approximately 58 percent are Title I eligible schools and 7.4 percent are magnet schools. ${ }^{16}$ Fortyone percent of students in the sample were eligible for free or reduced lunch. About 22 percent of the 4,415 principals were in their first year of tenure at a school, 19 percent in their second year, 15 percent in their third, and 44 percent had been at the same school for four or more years, showing that there was considerable turnover of principals among North Carolina's schools,

\footnotetext{
${ }^{15}$ The results are similar if we drop middle/junior high schools from the analysis.

16 Title I eligible schools are schools in which at least 40 percent of the enrollment of the school come from low-income families.
} 
which helped us to identify the fixed effects of principals. About 14 percent were in their first year of employment as a principal, and 62 percent had been a principal for four or more years; their average monthly state salary was roughly US $\$ 6,000$. About 28 percent had an advanced degree — generally a graduate degree that has no effect on salary and that staff are not required to report — and 9 percent had a doctorate. We also included a measure of competitiveness of the principal's undergraduate and graduate institutions. Following the literature on teacher quality, we assigned each principal's institution a competitive ranking based on information from Barron's Profiles of American Colleges, 25th ed.; 16 percent of principals obtained their bachelor's degree from a “competitive” school, but only 2 to 4 percent received advanced degrees or doctorates from a "competitive” school.

\section{Principal Mobility}

Because our estimates of principals' value added from equation (1) rely on mobility when school effects are included in the model, it is informative to examine how principals moved between schools. Table 3 describes the mobility of principals in our sample and contains basic statistics about the number and mobility of principals in North Carolina between 1998 and 2009. Between 1,560 and 1,790 principals were employed each year, of whom between 197 and 291 each year were newly hired into the system. The main factors affecting the number of principals hired each year are retirements in the previous year and school openings or closings in a particular year.

Between 74.4 and 80.3 percent of principals stayed in the same school from one year to the next, 8.6 to 10.8 percent moved to a different school within the state, and 10.2 to 14.9 percent left the sample. Of those that left, approximately 20 percent continued to work for the North Carolina Department of Instruction in another role, such as a superintendent, assistant principal, teacher, 
or other educational support staff; the other 80 percent retired, moved out of state, or left the public education sector.

The identifying assumption in our main estimation strategy for the effects of principals is that mobility is exogenous, conditional on all the control variables in our model. If principals prefer schools with particular fixed attributes, this does not affect the causal interpretation in our model with school fixed effects or in our model without school fixed effects if we control for those fixed factors. However, our estimates of the effects of principals might be biased if timevarying characteristics of a school or community relate to principal mobility and student achievement; ${ }^{17}$ we therefore control for a large variety of such characteristics in our analysis (see Tables 1 and 2).

To examine this issue in detail, we empirically evaluated the determinants of principal mobility; the results are shown in Table 4. We included all schools in our sample and regressed an indicator for a principal move between $t$ and $t+1$ on school, principal, and community characteristics at time $t$ (and, in some specifications, $t-1$ ). In columns 1-6 of Table 4, the dependent variable equals 1 only if the principal moves from one school to another in the sample; in columns 7-12, the indicator equals 1 for any move, including switches to schools out of the sample or exits from the sample. We report estimates for a variety of different test-score measures, including average school-level math and reading scores, lag-average-school-level scores, average gain scores in math and reading, lag-average-gain scores, the year-to-year

\footnotetext{
${ }^{17}$ For example, if school districts chose not to renew contracts of principals who performed poorly on current or lagged test scores due to random fluctuations or one-time shocks to student performance, and if these test scores were mean-reverting, we mistakenly might attribute an improvement in scores to a new principal when in fact it was just mean reversion.
} 
difference in level scores for each school, and the difference in school-average gains between years $t$ and $t-1$. None of these coefficients is statistically significant. We repeat the same exercise in columns 7-12 using all principal switches, where we find some evidence of principal turnover based on math test scores. ${ }^{18}$ We report the coefficients for the other variables in each specification in Appendix Table A-1. There is some evidence that the fraction in special education and the number of students in a school are related to mobility in the school-to-school movers, ${ }^{19}$ while the number of Title 1 eligible schools and the fraction of black individuals in a community are related in the all-movers regression. The main significant predictor of mobility in all specifications, however, is the principal's tenure in a school: the longer the tenure in a school, the more likely the principal is to move. Therefore, we cannot be certain that mobility is unrelated to unobservable factors that change during our time period, but these results provide some evidence that very few observable factors are related to mobility. ${ }^{20}$

\footnotetext{
${ }^{18}$ All scores are measured in student-level standard deviations. Note that one student-level standard deviation is roughly equal to two school-level standard deviations. We have run all our analysis on the subsample of principals that only switch from school to school and all the results are similar.

${ }^{19}$ Number of students in a school is related to mobility because principal salaries are based partly on the size of the school and therefore principals have an incentive to move to larger schools. ${ }^{20}$ In the context of teacher effects, Rothstein (2010) examines variation across current teachers in lagged test score gains as a test for non-random sorting within schools. Because it focuses on detecting within-school sorting across teachers, it is not appropriate to conduct this test in the context of principal effects. In particular, we suspect that a main reason why some principals are more effective than others is because they are better at allocating students to classrooms. Note
} 


\section{Results}

\section{A. Variation in Principal Quality}

Table 5 reports standard deviations for the estimated value added of principals from equation (1). In math, the standard deviation is 0.132 without school fixed effects and 0.183 when school effects are included. ${ }^{21}$ The standard deviation rises after including school fixed effects because the principal and school effects are negatively correlated, which is to say that high value added principals tend to be in low value added schools. ${ }^{22}$ An explanation for this phenomenon is

also that our results are in line with Miller (2013) who finds that principal turnover in North Carolina does not have a large effect on school performance. However, Miller (2013) does find a drop in test scores preceding a principal departure using a subsample of our data, whereas our analysis does not support this conclusion.

${ }^{21}$ We include dummies for principal tenure in our regressions. An incorrect specification of tenure effects could introduce error. Therefore, we have run the analysis without tenure controls and find similar estimates. These estimates are available from the authors upon request. We have also run the analysis with experience controls and find similar estimates. These estimates are also available from the authors upon request.

${ }^{22}$ To show this, we follow Dhuey and Smith (2013). Suppose we run an OLS regression of test scores on only principal effects, and obtain $y_{i}=\hat{\delta}_{p}+e_{i}$. Aggregating to the principal level, we get $\bar{y}_{p}=\hat{\delta}_{p}$ because the OLS residual sums to zero for each principal. Now suppose we include school effects in the regression and get $y_{i}=\hat{\delta}_{p}^{*}+\phi_{p}+e_{i}^{*}$. Aggregating to the principal level, we get $\bar{y}_{p}=\hat{\delta}_{p}^{*}+\overline{\hat{\phi}}_{p}$ again because the residual sums to zero for each principal. Combining the two equations, we get $\hat{\delta}_{p}=\hat{\delta}_{p}^{*}+\bar{\phi}_{p}$. The variance is $\operatorname{VAR}\left(\hat{\delta}_{p}\right)=\operatorname{VAR}\left(\hat{\delta}_{p}^{*}\right)+\operatorname{VAR}\left(\overline{\hat{\phi}}_{p}\right)+$ 
compensatory matching, where higher quality principals are purposefully assigned to less effective schools in order to improve school performance. A similar negative correlation is found in other principal value added studies using data from British Columbia, Canada (Dhuey and Smith, 2013) and Pennsylvania (Chiang, Lipscomb and Gill, 2012). Adjusting for sampling error reduces both estimates, but by very little, reflecting the large number of students each principal influences. There is less variation in value added in reading, where the standard deviation is 0.101 without school effects and 0.136 with school effects. ${ }^{23}$ It is vital to control for school fixed $2 \operatorname{COV}\left(\hat{\delta}_{p}^{*}, \bar{\phi}_{p}\right)$. We can use this to show that $\operatorname{VAR}\left(\hat{\delta}_{p}^{*}\right)>\operatorname{VAR}\left(\hat{\delta}_{p}\right)$ if $\operatorname{COV}\left(\hat{\delta}_{p}^{*}, \overline{\hat{\phi}}_{p}\right) / \operatorname{VAR}\left(\overline{\hat{\phi}}_{p}\right)<-1 / 2$, which will occur if the principal and school effects are negatively correlated.

${ }^{23}$ We performed various robustness checks and we report the results for the school fixed effects specification here. First, we computed the adjusted standard deviation using each principal's total number of students as weights (Rothstein 2010), which returned a standard deviation of 0.158 in math and 0.113 in reading. Second, we assume that the underlying true principal effects are Normally distributed, and estimate their variance using Maximum Likelihood (Rockoff 2004), yielding a standard deviation is 0.160 in math and in 0.096 in reading. When we run the analysis from Table 5 using only principals who switched schools, the standard deviation of the principal fixed effects is 0.195 in math and 0.141 in reading (adjusted standard deviations are 0.181 and 0.117). We also ran regressions with a set of teacher control variables for each students, including education, experience, licensing, certification, race, and gender. To ensure the correct teacher characteristics were matched with the student, we used a subsample of grade 4-5 students. The standard deviation across the 3212 principals for this subsample when teacher variables are excluded is 0.175 in math and 0.113 in reading ( 0.163 and 0.091 adjusted), and 
effects when calculating principals' value added because we need to disentangle the effect of individual principals from the fixed characteristics of the schools they lead — if principals sort into schools based on the schools' fixed characteristics, our estimates of the fixed effect of principals without school fixed effects will be biased.

Our analysis thus far provides estimates of principal effects that are fixed across schools (and time). It is entirely plausible, however, that a principal's effectiveness varies from one school to another. These "match effects" might arise if a principal's effect on student achievement depends on things like interactions with the existing teaching staff, the demographic composition of the student body, the principal's own location preference, or any other complementarity between the principal and school.

We use Woodcock’s (2011) methods for estimating match effects alongside principal and school effects. The estimator is a hybrid random-effects estimator that first nets out the effect of observables from the dependent variable using the usual fixed-effects assumptions, then estimates the variances of the principal, school, and match effects, treating them as random effects. The estimator first estimates the parameters on the observables (i.e. everything except the principal, school, and match effects) by OLS, using principal-by-school fixed effects. These estimated parameters are then used in a restricted maximum likelihood framework to estimate the variance of the principal, school, and match effects. The estimated variances are then used to predict the fixed effects. Jackson (forthcoming) uses a similar estimation strategy to examine teacher matches. Because identifying match effects separately from principal and school effects demands a lot of the data, and because both estimation methods have potential downsides, we

when they are included the standard deviations are 0.174 in math and 0.111 in reading $(0.162$ and 0.088 adjusted). 
present match-effect estimates for descriptive purposes only, and do not use them for further analysis. $^{24}$

We find that the standard deviation of the principal effect from Table 5 shrinks to onefifth its size in math and to just above one-tenth its size in reading when match-effects are included in the analysis. The match-effect standard deviation is 0.073 in math and 0.043 in reading. Based on these estimates, much of the principal effect we observe might be related to the match between principal and school, rather than an effect that principals can carry from one school to another. If this is indeed the case, then good policy should take match effects into account when allocating principals to schools.

Given the substantial variation in principals’ ability to influence student test-score gains in math and reading, it is natural to ask why some principals are better than others at generating gains. As a first step toward answering this question, we take the estimates of the principal effects and regress them on a set of variables that measures principals’ education level and quality, with one observation per principal. Table 7 presents the results of this exercise. Having a doctorate from a non-competitive institution has a small positive effect on the principal's value added in math, and having an advanced degree from either a competitive or non-competitive institution has a positive influence on the principal's value added in reading.

To summarize, we find considerable variation in principal value added in both reading and math in North Carolina. Although our main estimates attribute these differences entirely to principals' fixed attributes, our match-effect estimates suggest that at least part of the principal's effect depends on the match with the school. In looking at what makes some principals better

\footnotetext{
24 The hybrid random-effects estimator of the variances assumes orthogonality between the three effects and the error term, which may not be justified.
} 
able to improve student test scores than others, we find that a principal's education plays a small role, particularly with respect to reading.

\section{B. Changes of Principal and School Inputs and Outcomes}

What effect does a change in principal have on school inputs and outcomes? In this section, we present results of regressions of various outcomes for schools that changed principals, depending on the incoming principal's value added relative to that of the outgoing principal and whether or not the incoming principal was appearing in the data for the first time. ${ }^{25}$ For these regressions, we based differences in value added on the average of each principal's value added in math and reading. The goal was to estimate what happens the year (or a few years after) a school receives a new principal. To do so, we tested whether the principal's contribution to improving math and reading scores translated into improvements in other inputs or outcomes. Conversely, we also tested whether an incoming principal with lower value added led these outcomes to fall. Finally, we tested whether the principal's value added to test scores was related to changes in such school inputs as the complement of teachers.

We are interested in the effect of principal changes on a variety of school-level inputs and outcomes. These are related to the actions or policies of a principal that might have an indirect effect on future student performance, and should therefore give some perspective on how principals of varying value added affect student outcomes. We examined the school's percentage of AYP (as defined by the No Child Left Behind Act) targets met, measures of student disruption

\footnotetext{
${ }^{25}$ Although we cannot be sure that all principals we observed for the first time in the data were brand-new principals (since they might have worked as a principal in another state or at a private school), we interpret them as such.
} 
such as crime and suspensions, average daily attendance, and several measures related to teachers, such as turnover, licensing, education, and experience. These measures allow us to paint a fairly broad picture of the types of inputs and outcomes principals influence when they switch school.

The coefficients in Table 8, panel A, measure the immediate effect in year t of a principal change on our package of outcomes. ${ }^{26}$ We find that replacing the current principal with one whose value added is lower decreases the fraction of long-term suspensions, which might indicate that such a principal is less able to handle school disruptions; however, it could also reflect a lessening of disruption in the school overall. Replacing the current principal with one whose value added is higher decreases the percentage of National Board Certified teachers and increases the fraction of new teachers. Again, this finding has policy implications. Both Clotfelter et al (2007) and Goldhaber and Anthony (2007) suggest that teachers who select into receiving such certification are overall better teachers but that the certification does not improve their quality, as measured by test-score gains. Moreover, such teachers are more expensive: in North Carolina, they receive an increase of 12 percent of their base pay upon certification. We also find that replacing the current principal with one not seen before in the data moderately increases the teacher turnover rate. In a forthcoming paper, Ronfeldt, Loeb, and Wykoff find that students who experience a higher turnover of teachers have lower scores in both English language arts and math, and that teacher turnover has a disruptive effect separate from its possibly changing the distribution of teachers’ quality in a school.

\footnotetext{
${ }^{26}$ We reestimate these coefficients with school-specific linear time trends, and report the results in Appendix Table A-2.
} 
Table 8, panel B, presents the cumulative effect over three years of a change of principals therefore the coefficient thus measures the cumulative effect in years $t$ to $t+2$ of changing the principal at the beginning of year $t$. The coefficients are much the same as in panel $\mathrm{A}$, with a couple of notable exceptions. If the new principal has no experience, within three years there is a decrease in the percentage of daily attendance, an increase in teachers with little experience, a decline in teachers with 11 or more years of experience, and a decline in AYP targets met. In addition, we also continue to find an increase in teacher turnover rate.

As Table 8 shows, new principals do not have a particularly significant effect on schools’ non-test-score inputs and outcomes, but some of the results are interesting. The relationship between the characteristics of teachers and principals new to the sample suggests that having a brand-new principal might detrimental to students over the first three years of the principal's tenure. At the same time, with the absence of any relationship between many measures of teachers and student discipline and principals' value added, the only clear picture that emerges is that the inputs and outcomes we examined do not explain fully how good principals improve students' test scores.

\section{Conclusion}

Principals have a large effect on students' math and reading test scores, and much of the effect is likely related to the match between the principal and the school; a principal's education also plays a small role in improving students' scores. Principals with high valued added increase test scores, those with low value added or who are new reduce scores. Despite examining a variety of school inputs and outcomes, however, we could find only part of the puzzle in which to help us disentangle the contributions that high- and low-value-added principals make to their schools and 
students. Regardless, these results have important implications for policy. In particular, it is possible that using available test-score data, policymakers could identify the most effective principals and allocate them among schools to reduce gaps in achievement. However, policymakers need to be very careful in calculating these measures as it is important to separately identify the principal from the school fixed effect. As seen in this manuscript, this requires a long span of high quality longitudinal data along with exogenous principal mobility after controlling for observable characteristics of the students, schools, and neighborhoods. These are large and probably unattainable requirements for many states and school districts. Finally, more work needs to be undertaken to continue to uncover what makes a good principal good.

\section{References}

Branch, Gregory F., Eric A. Hanushek, and Steven G. Rivkin. 2012. "Estimating the Effect of Leaders on Public Sector Productivity: The Case of School Principals.” NBER Working Paper 17803. Cambridge, MA: National Bureau of Economic Research.

Beteille, Tara, Demetra Kalogrides, and Susanna Loeb. 2012. “Stepping Stones: Principal Career Paths and School Outcomes.” Social Science Research 41(4): 904-19.

Cannon, Sarah, David Figlio, and Tim Sass. 2012. "Principal Quality and the Persistence of School Policies.” Unpublished manuscript. 
Chiang, Hanley, Stephen Lipscomb, and Brian Gill. 2012. "Is School Value-Added Indicative of Principal Quality?” Working paper. Princeton, NJ: Mathematica Policy Research.

Clark, Damon, Paco Martorell, and Jonah Rockoff. 2009. "School Principals and School Performance.” Working Paper 38. Washington, DC: Urban Institute.

Clotfelter, Charles T., Helen F. Ladd, and Jacob L. Vigdor. 2007. “Teacher Credentials and Student Achievement: Longitudinal Analysis with Student Fixed Effects.” Economics of Education Review 26(6): 673-82.

Coelli, Michael, and David Green. 2012. "Leadership Effects: School Principals and Student Outcomes.” Economics of Education Review 31(1): 92-109.

Cullen, Julie, and Michael J. Mazzeo. 2007. “Implicit Performance Awards: An Empirical Analysis of the Labor Market for Public School Administrators.” Unpublished manuscript.

Dhuey, Elizabeth, and Justin Smith. 2012. "How Important Are Principals in the Production of School Achievement?” Unpublished manuscript.

Goldhaber, Dan, and Emily Anthony. 2007. “Can Teacher Quality Be Effectively Assessed? National Board Certification as a Signal of Effective Teaching.” Review of Economics and Statistics 89(1): 134-50. 
Grissom, Jason A., Demetra Kalogrides, and Susanna Loeb. 2012. “Using Student Test Scores to Measure Principal Performance.” Unpublished manuscript.

Grissom, Jason A., and Susanna Loeb. Forthcoming. "Triangulating Principal Effectiveness: How Perspectives of Parents, Teachers, and Assistant Principals Identify the Central Importance of Managerial Skills.” American Educational Research Journal.

Hallinger, Philip, and Ronald H. Heck. 1998. “Exploring the Principal’s Contribution to School Effectiveness: 1980-1995.” School Effectiveness and School Improvement 9(2):157-91.

Hanushek, Eric A. 2006. “Teacher Quality.” In Handbook of the Economics of Education, vol. 2, edited by Eric A. Hanushek and Finish Welch. Amsterdam: Elsevier.

Horng, Eileen Lai, Daniel Klasik, and Susanna Loeb. 2009. "Principal Time-Use and School Effectiveness.” CALDER Working Paper 34. Washington, DC: Urban Institute.

Jackson, C. Kirabo. Forthcoming. "Match Quality, Worker Productivity, and Worker Mobility: Direct Evidence from Teachers.” The Review of Economics and Statistics.

Jacob, Brian, and Lars Lefgren. 2005 “Principals as Agents: Subjective Performance Measurement in Education” NBER Working Paper 11463, Cambridge, MA: National Bureau of Economic Research. 
Li, Danielle. 2011. "School Accountability and Principal Mobility: How No Child Left Behind Affects the Allocation of School Leaders.” Unpublished manuscript.

Mihaly, Kata, Daniel McCaffrey, J.R. Lockwood, and Tim R. Sass. 2010. "Centering and Reference Groups for Estimates of Fixed Effects: Modifications to felsdvreg.” Stata Journal 10(1): 82-103.

Miller, Ashley. 2013. “Principal Turnover and Student Achievement.” Economics of Education Review 36 (October): 60-72.

Rockoff, Jonah E. 2004. “The Impact of Individual Teachers on Student Achievement: Evidence from Panel Data.” American Economic Review 94(2): 247-52.

Ronfeldt, Matthew, Susanna Loeb, and James Wykoff. Forthcoming. "How Teacher Turnover Harms Student Achievement.” American Educational Research Journal.

Rothstein, Jesse. 2010. “Teacher Quality in Educational Production: Tracking, Decay, and Student Achievement.” Quarterly Journal of Economics 125(1): 175-214.

Woodcock, Simon. 2011. "Match Effects.” Unpublished manuscript. 
Table 1

Descriptive statistics for students in analysis sample

\begin{tabular}{|c|c|c|}
\hline & Mean & Std Dev. \\
\hline \multicolumn{3}{|l|}{ Math scores } \\
\hline Grade 3 & 0.067 & 0.960 \\
\hline Grade 4 & 0.038 & 0.986 \\
\hline Grade 5 & 0.041 & 0.986 \\
\hline Grade 6 & 0.054 & 0.983 \\
\hline Grade 7 & 0.055 & 0.986 \\
\hline Grade 8 & 0.052 & 0.984 \\
\hline \multicolumn{3}{|l|}{ Reading scores } \\
\hline Grade 3 & 0.063 & 0.958 \\
\hline Grade 4 & 0.029 & 0.987 \\
\hline Grade 5 & 0.032 & 0.983 \\
\hline Grade 6 & 0.047 & 0.975 \\
\hline Grade 7 & 0.048 & 0.975 \\
\hline Grade 8 & 0.046 & 0.973 \\
\hline \multicolumn{3}{|c|}{ Student demographic characteristics } \\
\hline Male & 0.501 & 0.500 \\
\hline Black & 0.286 & 0.452 \\
\hline Hispanic & 0.054 & 0.227 \\
\hline White & 0.606 & 0.489 \\
\hline Other race & 0.053 & 0.224 \\
\hline Special education & 0.092 & 0.289 \\
\hline Gifted & 0.140 & 0.347 \\
\hline Learning disabled in math & 0.020 & 0.140 \\
\hline Learning disabled in reading & 0.041 & 0.199 \\
\hline Number of students & \multicolumn{2}{|c|}{$1,664,158$} \\
\hline Number of observations & \multicolumn{2}{|c|}{$5,388,543$} \\
\hline
\end{tabular}


Table 2

Descriptive statistics for schools and principals in analysis sample

\begin{tabular}{|c|c|c|}
\hline & Mean & Std Dev. \\
\hline \multicolumn{3}{|l|}{ School characteristics } \\
\hline Fraction male & 0.515 & 0.048 \\
\hline Fraction white & 0.572 & 0.281 \\
\hline Fraction black & 0.305 & 0.255 \\
\hline Fraction other race & 0.056 & 0.082 \\
\hline Fraction hispanic & 0.067 & 0.080 \\
\hline Fraction in special education & 0.123 & 0.069 \\
\hline Fraction Gifted & 0.103 & 0.091 \\
\hline Fraction learning disabled in math & 0.025 & 0.020 \\
\hline Fraction learning disabled in reading & 0.050 & 0.029 \\
\hline Percent eligible for free/reduced lunch & 0.408 & 0.216 \\
\hline Title 1 eligible school & 0.581 & 0.492 \\
\hline Number of full-time teachers & 37.444 & 14.947 \\
\hline Magnet school & 0.074 & 0.261 \\
\hline Number of students in school & 552.324 & 241.571 \\
\hline Pupil/teacher ratio & 14.743 & 3.757 \\
\hline \multicolumn{3}{|l|}{ Neighborhood census characteristics } \\
\hline Fraction male & 0.487 & 0.018 \\
\hline Fraction white & 0.707 & 0.206 \\
\hline Fraction black & 0.227 & 0.187 \\
\hline Fraction other race & 0.052 & 0.072 \\
\hline Fraction hispanic & 0.057 & 0.044 \\
\hline Fraction under 18 years old & 0.242 & 0.033 \\
\hline Fraction over 65 years old & 0.129 & 0.040 \\
\hline Fraction married & 0.510 & 0.112 \\
\hline Fraction renters & 0.310 & 0.121 \\
\hline Number of schools & \multicolumn{2}{|c|}{1,954} \\
\hline \multicolumn{3}{|l|}{ Principal characteristics } \\
\hline 1 year of tenure & 0.218 & 0.413 \\
\hline 2 years of tenure & 0.192 & 0.394 \\
\hline 3 years of tenure & 0.148 & 0.355 \\
\hline 4 years or more of tenure & 0.442 & 0.497 \\
\hline 1 year of experience & 0.136 & 0.343 \\
\hline 2 years of experience & 0.128 & 0.334 \\
\hline 3 years of experience & 0.112 & 0.316 \\
\hline 4 years or more of experience & 0.623 & 0.485 \\
\hline Monthly state salary (\$) & 5992.939 & 888.664 \\
\hline Advanced degree & 0.279 & 0.449 \\
\hline Doctorate degree & 0.090 & 0.287 \\
\hline Competitive bachelor's school & 0.164 & 0.371 \\
\hline Competitive master's school & 0.126 & 0.332 \\
\hline Competitive advanced degree school & 0.036 & 0.186 \\
\hline Competitive doctorate school & 0.024 & 0.155 \\
\hline Number of principals & \multicolumn{2}{|c|}{4,415} \\
\hline
\end{tabular}

Notes: Figures are based on 20,188 school-year observations on schools over time. All statistics in the table are averages across 20,188 observations. Monthly state salary is based on the North Carolina salary schedule, and is reported in constant 2009 dollars. Years of tenure is the amount of time a principal is observed in a particular school at time $t$, while years of experience is the number of years observed in the data at time $t$. 
Table 3

Mobility of principals

\begin{tabular}{|c|c|c|c|c|c|c|c|c|c|c|c|c|}
\hline Year & 1998 & 1999 & 2000 & 2001 & 2002 & 2003 & 2004 & 2005 & 2006 & 2007 & 2008 & 2009 \\
\hline Total employed & 1,560 & 1,583 & 1,617 & 1,634 & 1,649 & 1,674 & 1,699 & 1,706 & 1,736 & 1,750 & 1,758 & 1,790 \\
\hline New hires & 203 & 211 & 209 & 197 & 196 & 208 & 230 & 251 & 276 & 291 & 248 & 222 \\
\hline Same school next year & 0.799 & 0.795 & 0.802 & 0.796 & 0.803 & 0.784 & 0.779 & 0.760 & 0.744 & 0.769 & 0.783 & \\
\hline Different school next year & 0.086 & 0.099 & 0.092 & 0.102 & 0.090 & 0.098 & 0.098 & 0.099 & 0.108 & 0.103 & 0.094 & \\
\hline
\end{tabular}

Notes: Summary statistics are based on a population of 20,188 observations on 4,415 principals in 1,954 schools; 32 observations of principals who worked in two different schools in the same year were dropped in this table but included in subsequent analyses. New hires are principals who were not in the sample in $t$ Principals who are "out of sample" in year $t+1$ are no longer observed in the data. 
Table 4

Regression of principal turnover on school test scores

Average school-level math scores

Average school-level reading scores

Lag-average school-level math scores

Lag-average school-level reading scores

Average gain in math scores

Average gain in reading scores

Lag-average gain in math scores

Lag-average gain in reading scores

Difference in levels between year $t$ and $t-1$ math

Difference in levels between year $t$ and $t-1$ reading

Difference in school-average gains between year $t$ and $t-1$ math

Difference in school-average gains between year $t$ and $t-1$ reading

\begin{tabular}{|c|c|c|c|c|c|c|c|c|c|c|c|}
\hline \multicolumn{6}{|c|}{ School to school switch } & \multicolumn{6}{|c|}{ All switches } \\
\hline (1) & $(2)$ & (3) & (4) & (5) & (6) & (7) & (8) & (9) & (10) & (11) & (12) \\
\hline-0.013 & -0.017 & & & & & $-0.109 * * *$ & $-0.096 * *$ & & & & \\
\hline$(0.024)$ & $(0.029)$ & & & & & $(0.039)$ & $(0.044)$ & & & & \\
\hline 0.007 & 0.020 & & & & & -0.033 & -0.017 & & & & \\
\hline$(0.029)$ & $(0.034)$ & & & & & $(0.046)$ & $(0.053)$ & & & & \\
\hline & 0.002 & & & & & & 0.006 & & & & \\
\hline & $(0.028)$ & & & & & & $(0.044)$ & & & & \\
\hline & 0.016 & & & & & & -0.019 & & & & \\
\hline & $(0.032)$ & & & & & & $(0.051)$ & & & & \\
\hline & & 0.009 & -0.009 & & & & & $-0.073^{* *}$ & $-0.074 * *$ & & \\
\hline & & $(0.021)$ & $(0.023)$ & & & & & $(0.033)$ & $(0.036)$ & & \\
\hline & & -0.001 & -0.003 & & & & & 0.008 & -0.036 & & \\
\hline & & $(0.029)$ & $(0.032)$ & & & & & $(0.044)$ & $(0.048)$ & & \\
\hline & & & 0.022 & & & & & & -0.002 & & \\
\hline & & & $(0.024)$ & & & & & & $(0.035)$ & & \\
\hline & & & 0.003 & & & & & & -0.071 & & \\
\hline & & & $(0.034)$ & & & & & & $(0.049)$ & & \\
\hline & & & & -0.011 & & & & & & -0.044 & \\
\hline & & & & $(0.023)$ & & & & & & $(0.035)$ & \\
\hline & & & & 0.002 & & & & & & 0.002 & \\
\hline & & & & (0.027) & & & & & & $(0.042)$ & \\
\hline & & & & & -0.015 & & & & & & -0.035 \\
\hline & & & & & $(0.015)$ & & & & & & $(0.024)$ \\
\hline & & & & & -0.003 & & & & & & 0.017 \\
\hline & & & & & $(0.020)$ & & & & & & $(0.030)$ \\
\hline 18,277 & 16,295 & 18,277 & 16,295 & 16,295 & 16,295 & 18,277 & 16,295 & 18,277 & 16,295 & 16,295 & 16,295 \\
\hline
\end{tabular}

Number of observations

$\begin{array}{llllllllllll}18,277 & 16,295 & 18,277 & 16,295 & 16,295 & 16,295 & 18,277 & 16,295 & 18,277 & 16,295 & 16,295 & 16,295\end{array}$

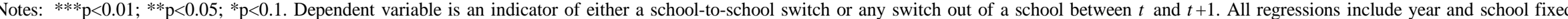

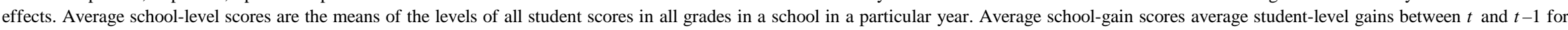

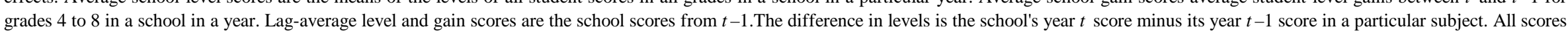
are measured in student-level standard deviations; one student-level standard deviation is roughly equal to two school-level standard deviations. Standard errors are clustered by school. 
Table 5

Student-level estimates of principal fixed effects

\begin{tabular}{|c|c|c|c|c|}
\hline & \multicolumn{2}{|c|}{ Math } & \multicolumn{2}{|c|}{ Reading } \\
\hline & $(1)$ & $(2)$ & $(3)$ & $(4)$ \\
\hline Standard deviation & 0.132 & 0.183 & 0.101 & 0.136 \\
\hline Adjusted standard deviation & 0.128 & 0.172 & 0.096 & 0.117 \\
\hline 10th percentile & -0.151 & -0.210 & -0.108 & -0.139 \\
\hline 25th percentile & -0.076 & -0.081 & -0.051 & -0.054 \\
\hline 50th percentile & 0.004 & 0.000 & 0.002 & 0.001 \\
\hline 75th percentile & 0.082 & 0.080 & 0.060 & 0.057 \\
\hline 90th percentile & 0.158 & 0.214 & 0.116 & 0.152 \\
\hline (75th percentile - median) & 0.078 & 0.080 & 0.058 & 0.056 \\
\hline \multicolumn{5}{|l|}{ Fixed effects: } \\
\hline School & no & yes & no & yes \\
\hline
\end{tabular}


Table 6

Estimates of match effects

\begin{tabular}{lcc}
\hline & $\begin{array}{c}\text { Math } \\
(1)\end{array}$ & $\begin{array}{c}\text { Reading } \\
(2)\end{array}$ \\
\hline Standard deviation for principal & 0.039 & 0.019 \\
Standard deviation for school & 0.127 & 0.100 \\
Standard deviation for match & 0.073 & 0.043 \\
\hline Notes: Statistics in this table are based on the same sample and control variables used in Table 5. \\
There are 4,415 principals, 1,954 schools, and 5,783 matches. Standard deviations are Restricted \\
Maximum Likelihood (REML) estimates. In fixed-effects models, the principal, school, and \\
match effects are centered within connected groups.
\end{tabular}


Table 7

Relationship between principal quality and education

\begin{tabular}{lcc}
\hline & Math & Reading \\
& $(1)$ & $(2)$ \\
\hline Competitive bachelor's school & 0.0004 & 0.0040 \\
Competitive master's school & $(0.0078)$ & $(0.0054)$ \\
& -0.0062 & 0.0007 \\
Competitive doctorate school & $(0.0084)$ & $(0.0059)$ \\
Non-competitive doctorate school & -0.0170 & -0.0093 \\
& $(0.0178)$ & $(0.0128)$ \\
Competitive advanced degree school & $0.0201 * *$ & 0.0120 \\
& $(0.0102)$ & $(0.0079)$ \\
Non-competitive advanced degree school & 0.0062 & $0.0219^{* *}$ \\
& $(0.0131)$ & $(0.0107)$ \\
Number of observations & -0.0023 & $0.0103 * *$ \\
\end{tabular}

Notes: ${ }^{* * *} \mathrm{p}<0.01 ;{ }^{* *} \mathrm{p}<0.05 ;{ }^{*} \mathrm{p}<0.1$. Education variables are indicator variables equal to 1 if the principal ever had the particular degree. Standard errors are robust to heteroskedasticity. 
Table 8

Effect of new principals on school-level inputs and outcomes

\begin{tabular}{|c|c|c|c|c|c|c|c|c|c|c|c|c|}
\hline & $\begin{array}{c}\text { \% AYP } \\
\text { target met } \\
(1)\end{array}$ & $\begin{array}{c}\text { Crime } \\
(2)\end{array}$ & $\begin{array}{c}\text { Long-term } \\
\text { suspensions } \\
\text { (3) } \\
\end{array}$ & $\begin{array}{c}\text { Daily } \\
\text { attendance } \\
(\%) \\
(4) \\
\end{array}$ & $\begin{array}{c}\text { Teachers } \\
\text { with } \\
\text { advanced } \\
\text { degree (\%) } \\
\text { (5) }\end{array}$ & $\begin{array}{c}\text { Teacher } \\
\text { turnover rate } \\
\text { (\%) } \\
(6) \\
\end{array}$ & $\begin{array}{c}\text { Licensed } \\
\text { teachers (\%) } \\
(7) \\
\end{array}$ & $\begin{array}{c}\text { National } \\
\text { Board } \\
\text { Certified } \\
\text { teachers (\%) } \\
(8) \\
\end{array}$ & $\begin{array}{c}\text { \% Classes w/ } \\
\text { highly } \\
\text { qualified } \\
\text { teachers } \\
\text { (9) }\end{array}$ & $\begin{array}{c}\text { \% Teachers } 0 \\
3 \text { yrs } \\
\text { experience } \\
(10) \\
\end{array}$ & $\begin{array}{c}\text { 0. \% Teachers } 4 \text { - } \\
10 \text { yrs } \\
\text { experience } \\
(11) \\
\end{array}$ & $\begin{array}{c}\text { \% Teachers } \\
11+\text { yrs } \\
\text { experience } \\
(12) \\
\end{array}$ \\
\hline \multicolumn{13}{|l|}{ Panel A: One year } \\
\hline Lower value added & $\begin{array}{c}0.000 \\
(0.013)\end{array}$ & $\begin{array}{c}0.005 \\
(0.068)\end{array}$ & $\begin{array}{c}-0.081^{* *} \\
(0.035)\end{array}$ & $\begin{array}{c}0.000 \\
(0.001)\end{array}$ & $\begin{array}{c}0.005 \\
(0.006)\end{array}$ & $\begin{array}{l}0.014 * \\
(0.008)\end{array}$ & $\begin{array}{c}0.007 \\
(0.005)\end{array}$ & $\begin{array}{c}0.004 \\
(0.004)\end{array}$ & $\begin{array}{l}-0.007 \\
(0.005)\end{array}$ & $\begin{array}{c}0.009 \\
(0.008)\end{array}$ & $\begin{array}{l}-0.003 \\
(0.008)\end{array}$ & $\begin{array}{l}-0.005 \\
(0.006)\end{array}$ \\
\hline Similar value added & $\begin{array}{l}-0.008 \\
(0.013)\end{array}$ & $\begin{array}{c}0.073 \\
(0.077)\end{array}$ & $\begin{array}{c}0.053 \\
(0.095)\end{array}$ & $\begin{array}{c}0.001 \\
(0.001)\end{array}$ & $\begin{array}{c}0.016^{* * *} \\
(0.005)\end{array}$ & $\begin{array}{c}0.007 \\
(0.009)\end{array}$ & $\begin{array}{l}-0.003 \\
(0.006)\end{array}$ & $\begin{array}{c}0.003 \\
(0.004)\end{array}$ & $\begin{array}{c}0.003 \\
(0.006)\end{array}$ & $\begin{array}{l}-0.008 \\
(0.007)\end{array}$ & $\begin{array}{l}0.012 * \\
(0.007)\end{array}$ & $\begin{array}{l}-0.003 \\
(0.007)\end{array}$ \\
\hline Higher value added & $\begin{array}{c}0.014 \\
(0.014)\end{array}$ & $\begin{array}{l}-0.100 \\
(0.102)\end{array}$ & $\begin{array}{l}-0.019 \\
(0.185)\end{array}$ & $\begin{array}{l}-0.002 \\
(0.001)\end{array}$ & $\begin{array}{l}-0.006 \\
(0.006)\end{array}$ & $\begin{array}{c}0.003 \\
(0.008)\end{array}$ & $\begin{array}{l}-0.009 \\
(0.006)\end{array}$ & $\begin{array}{c}-0.007^{*} \\
(0.004)\end{array}$ & $\begin{array}{c}0.007 \\
(0.008)\end{array}$ & $\begin{array}{l}0.014^{*} \\
(0.007)\end{array}$ & $\begin{array}{l}-0.006 \\
(0.007)\end{array}$ & $\begin{array}{l}-0.008 \\
(0.007)\end{array}$ \\
\hline First observation in data & $\begin{array}{l}-0.005 \\
(0.003)\end{array}$ & $\begin{array}{c}0.038 \\
(0.023)\end{array}$ & $\begin{array}{c}-0.047^{*} \\
(0.026)\end{array}$ & $\begin{array}{c}0.000 \\
(0.000)\end{array}$ & $\begin{array}{c}0.000 \\
(0.002)\end{array}$ & $\begin{array}{c}0.010^{* * *} \\
(0.002)\end{array}$ & $\begin{array}{l}-0.002 \\
(0.001)\end{array}$ & $\begin{array}{c}-0.001 \\
(0.001)\end{array}$ & $\begin{array}{c}0.001 \\
(0.002)\end{array}$ & $\begin{array}{c}0.002 \\
(0.002)\end{array}$ & $\begin{array}{l}-0.002 \\
(0.002)\end{array}$ & $\begin{array}{c}0.000 \\
(0.002)\end{array}$ \\
\hline \multicolumn{13}{|l|}{ Panel B: Three years } \\
\hline$\overline{\text { Lower value added }}$ & $\begin{array}{l}-0.002 \\
(0.010)\end{array}$ & $\begin{array}{c}0.012 \\
(0.066)\end{array}$ & $\begin{array}{l}-0.037 \\
(0.047)\end{array}$ & $\begin{array}{c}0.000 \\
(0.001)\end{array}$ & $\begin{array}{c}0.003 \\
(0.005)\end{array}$ & $\begin{array}{c}0.007 \\
(0.007)\end{array}$ & $\begin{array}{c}0.000 \\
(0.005)\end{array}$ & $\begin{array}{c}0.000 \\
(0.004)\end{array}$ & $\begin{array}{l}-0.007 \\
(0.006)\end{array}$ & $\begin{array}{c}0.004 \\
(0.007)\end{array}$ & $\begin{array}{c}0.004 \\
(0.006)\end{array}$ & $\begin{array}{c}-0.008 \\
(0.006)\end{array}$ \\
\hline Similar value added & $\begin{array}{c}0.011 \\
(0.011)\end{array}$ & $\begin{array}{c}0.010 \\
(0.076)\end{array}$ & $\begin{array}{c}0.198 \\
(0.226)\end{array}$ & $\begin{array}{l}0.001^{*} \\
(0.001)\end{array}$ & $\begin{array}{c}0.006 \\
(0.004)\end{array}$ & $\begin{array}{c}0.005 \\
(0.009)\end{array}$ & $\begin{array}{c}0.003 \\
(0.005)\end{array}$ & $\begin{array}{l}-0.001 \\
(0.003)\end{array}$ & $\begin{array}{l}-0.001 \\
(0.007)\end{array}$ & $\begin{array}{l}-0.001 \\
(0.006)\end{array}$ & $\begin{array}{c}0.006 \\
(0.007)\end{array}$ & $\begin{array}{l}-0.005 \\
(0.006)\end{array}$ \\
\hline Higher value added & $\begin{array}{c}0.010 \\
(0.010)\end{array}$ & $\begin{array}{c}-0.084 \\
(0.087)\end{array}$ & $\begin{array}{c}0.035 \\
(0.127)\end{array}$ & $\begin{array}{l}-0.001 * \\
(0.001)\end{array}$ & $\begin{array}{l}-0.007 \\
(0.005)\end{array}$ & $\begin{array}{l}-0.002 \\
(0.009)\end{array}$ & $\begin{array}{l}-0.005 \\
(0.005)\end{array}$ & $\begin{array}{l}-0.005 \\
(0.004)\end{array}$ & $\begin{array}{c}0.003 \\
(0.007)\end{array}$ & $\begin{array}{c}0.010 \\
(0.006)\end{array}$ & $\begin{array}{l}-0.007 \\
(0.006)\end{array}$ & $\begin{array}{l}-0.003 \\
(0.006)\end{array}$ \\
\hline First observation in data & $\begin{array}{c}-0.006 * * \\
(0.003)\end{array}$ & $\begin{array}{c}0.015 \\
(0.022)\end{array}$ & $\begin{array}{c}0.003 \\
(0.035)\end{array}$ & $\begin{array}{c}-0.001^{* * *} \\
(0.000)\end{array}$ & $\begin{array}{l}-0.001 \\
(0.002)\end{array}$ & $\begin{array}{c}0.008^{* * *} \\
(0.002)\end{array}$ & $\begin{array}{c}-0.003^{*} \\
(0.001)\end{array}$ & $\begin{array}{l}-0.001 \\
(0.001)\end{array}$ & $\begin{array}{c}0.002 \\
(0.002)\end{array}$ & $\begin{array}{l}0.005^{* *} \\
(0.002)\end{array}$ & $\begin{array}{l}-0.001 \\
(0.002)\end{array}$ & $\begin{array}{c}-0.004 * \\
(0.002)\end{array}$ \\
\hline Mean value of dep. variable & 0.931 & 0.419 & 0.240 & 0.951 & 0.258 & 0.169 & 0.934 & 0.119 & 0.949 & 0.228 & 0.289 & 0.483 \\
\hline Number of observations & 8,545 & 8,545 & $\begin{array}{c}6,717 \\
2003-04\end{array}$ & 9,936 & 9,936 & 9,936 & 9,936 & 8,545 & 8,545 & 9,936 & 9,936 & 9,936 \\
\hline Years included & 2003-09 & 2003-09 & 2006-09 & 2003-09 & 2003-09 & 2003-09 & 2003-09 & 2003-09 & 2003-09 & 2003-09 & 2003-09 & 2003-09 \\
\hline
\end{tabular}

Notes: ${ }^{* * *} \mathrm{p}<0.01 ;{ }^{* *} \mathrm{p}<0.05 ;{ }^{*} \mathrm{p}<0.1$. In panel A, the reported coefficients are based on indicators that are equal to 1 in the year of the principal switch. In panel B, indicators are equal to 1 in the year of the switch and subsequent two years following a principal change. If a school changes principals twice within two years, indicators are recoded to reflect the most current principal change. All regressions use the

average of math and reading value added for each principal. Regressions include school and year effects. Standard errors are clustered at the school level. 
Appendix Table A-1

Regression of principal turnover on school and neighborhood characteristics, Table 4 continued

Fraction male at school School to school switch

Fraction black at school

Fraction other race at school

Fraction Hispanic at school

Fraction in special education at school

Fraction learning disabled in math at school

Fraction learning disabled in reading at school

Fraction gifted at school

Percent eligible for free/reduced lunch at school

Title 1 eligible school

Number of full time teachers

Magnet school

Number of students in school

Pupil/teacher ratio

2 years of tenure

3 years of tenure

4 years or more of tenure

\begin{tabular}{|c|c|c|c|c|c|c|c|c|c|c|c|}
\hline \multicolumn{6}{|c|}{ School to school switch } & \multicolumn{6}{|c|}{ All switches } \\
\hline (1) & (2) & (3) & (4) & (5) & (6) & (7) & (8) & (9) & (10) & (11) & (12) \\
\hline 0.03 & 30 & 03 & & & 0.035 & 0.104 & & & & & \\
\hline$(0.071)$ & & 071) & $(0.078)$ & & & & & & 128) & & \\
\hline & & & & & & & & & & & \\
\hline$(0.062)$ & & $(0.059)$ & $(0.068)$ & $(0.068)$ & & & & $(0.086)$ & $(0.099)$ & & \\
\hline & & & & & & & & & & & \\
\hline$(0.131)$ & & $(0.131)$ & $(0.145)$ & & & & & $(0.203)$ & $(0.226)$ & & \\
\hline & & & 0.04 & & & & & 0.08 & & & \\
\hline$(0.091)$ & .102) & $(0.090)$ & $(0.100)$ & $(0.1$ & & & & $(0.136)$ & & & \\
\hline 06 & & & & & & & & & & & \\
\hline$(0.062)$ & 7) & $(0.061)$ & $(0.066)$ & $(0.0$ & & & & $(0.102)$ & $(0.113)$ & & \\
\hline-0.20 & & -0 & -0.076 & & & & & -0.048 & -0.078 & & \\
\hline$(0.18$ & $(0.206)$ & $(0.184)$ & $(0.206)$ & $(0.206)$ & $(0.2$ & & & $(0.297)$ & $(0.329)$ & & \\
\hline 0.05 & 005 & 0.045 & -0.013 & & & & & $.438 *$ & 0.432 & & \\
\hline 0.153 & & & & & & & & & & & \\
\hline & & & & & & & & & & & \\
\hline & & $(0.045)$ & $(0.049)$ & & & & & $(0.075)$ & $(0.083)$ & & \\
\hline & & & & & & & & & -0.0 & & \\
\hline & & $(0.024)$ & $(0.026)$ & & & & & & & & \\
\hline-0.0 & -0 & -0.014 & -0.016 & -0.0 & & -0.03 & & $-0.030 *$ & -0.02 & & \\
\hline$(0.00$ & (0.01 & (0.009) & $(0.010)$ & $(0.0$ & & & & $(0.015)$ & (0.01 & & \\
\hline & & & & & & & & 0.000 & 0.000 & & \\
\hline$(0.001)$ & $(0.001)$ & $(0.001)$ & $(0.001)$ & $(0.00$ & & & & $(0.001)$ & $(0.001)$ & & \\
\hline & & -0.01 & & & & & & 0.009 & 0.033 & & \\
\hline$(0.015)$ & $(0.017)$ & $(0.015)$ & (0.017) & $(0.0$ & $(0.0$ & $(0.02$ & $(0.023)$ & $(0.022)$ & $(0.023)$ & & \\
\hline $0.000 *$ & $0.000 *$ & $0.000 *$ & $0.000 *$ & 0.00 & $0.000 *$ & $0.000 * * *$ & $0.000 * * *$ & $0.000 * * *$ & $0.000 * *$ & 0.00 & 0.00 \\
\hline$(0.000)$ & & $(0.000)$ & $(0.000)$ & & & & & $(0.000)$ & & & \\
\hline & & -0.001 & -0.001 & -0.001 & & & -0.00 & $-0.003 *$ & -0.003 & & \\
\hline$(0.001)$ & $(0.001)$ & $(0.001)$ & $(0.001)$ & $(0.001)$ & $(0.001)$ & & $(0.002)$ & $(0.001)$ & (0.002) & & \\
\hline & $047 * * *$ & & & & & & & & $0.106 * * *$ & $0.106 * * *$ & \\
\hline$(0.006)$ & $(0.006)$ & $(0.006)$ & $(0.006)$ & & & & & & & & \\
\hline $0.073 * * *$ & $0.084 * * *$ & $0.073 * * *$ & $0.084 * * *$ & ก९^**** & $0.084 * * *$ & $0.164 * * *$ & $0.180 * * *$ & $0.162 * * *$ & $0.180 * *$ & $0179 * * *$ & $0.179 * *$ \\
\hline$(0.007)$ & $(0.007)$ & (0.007) & (0.007) & & & & & & & & \\
\hline $.093 * * *$ & $10\ulcorner * * *$ & (2) & & & $106 * * *$ & & & & & & \\
\hline
\end{tabular}


Fraction male in community

Fraction black in community

Fraction other race in community

Fraction hispanic in community

Fraction under 18 years old in community

Fraction over 65 years old in community

Fraction married in community

Fraction renters in community

Number of observations

$\begin{array}{cccccccccccc}(0.006) & (0.006) & (0.006) & (0.006) & (0.006) & (0.006) & (0.008) & (0.009) & (0.008) & (0.009) & (0.009) & (0.009) \\ 0.397 & 0.206 & 0.393 & 0.205 & 0.217 & 0.208 & 0.079 & -0.521 & 0.064 & -0.566 & -0.576 & -0.619 \\ (0.574) & (0.628) & (0.574) & (0.628) & (0.628) & (0.627) & (0.968) & (1.106) & (0.976) & (1.111) & (1.112) & (1.111) \\ -0.109 & -0.187 & -0.115 & -0.193 & -0.189 & -0.192 & -0.756^{* * *} & -0.748^{* *} & -0.809^{* * *} & -0.783^{* *} & -0.794^{* *} & -0.804^{* *} \\ (0.151) & (0.191) & (0.151) & (0.191) & (0.191) & (0.191) & (0.262) & (0.312) & (0.264) & (0.314) & (0.315) & (0.315) \\ -0.053 & -0.041 & -0.063 & -0.062 & -0.06 & -0.059 & -0.927^{* *} & -1.305^{* *} & -0.956^{* *} & -1.292^{* *} & -1.319^{* *} & -1.330^{* *} \\ (0.287) & (0.350) & (0.286) & (0.349) & (0.350) & (0.349) & (0.454) & (0.543) & (0.453) & (0.542) & (0.543) & (0.542) \\ -0.26 & -0.016 & -0.256 & -0.011 & -0.014 & -0.015 & 0.079 & 0.605 & 0.071 & 0.572 & 0.61 & 0.622 \\ (0.405) & (0.506) & (0.405) & (0.506) & (0.506) & (0.506) & (0.652) & (0.801) & (0.653) & (0.802) & (0.801) & (0.800) \\ 0.23 & -0.033 & 0.214 & -0.009 & -0.004 & -0.007 & 1.053 & 0.694 & 0.806 & 0.453 & 0.433 & 0.414 \\ (0.478) & (0.584) & (0.478) & (0.581) & (0.581) & (0.581) & (0.801) & (0.952) & (0.805) & (0.951) & (0.950) & (0.950) \\ 0.377 & 0.362 & 0.366 & 0.353 & 0.363 & 0.363 & 0.365 & -0.174 & 0.383 & -0.128 & -0.23 & -0.237 \\ (0.434) & (0.546) & (0.435) & (0.546) & (0.545) & (0.544) & (0.718) & (0.891) & (0.721) & (0.895) & (0.894) & (0.893) \\ -0.104 & -0.148 & -0.101 & -0.146 & -0.147 & -0.146 & -0.235 & -0.171 & -0.21 & -0.139 & -0.141 & -0.141 \\ (0.115) & (0.137) & (0.115) & (0.137) & (0.136) & (0.136) & (0.184) & (0.215) & (0.185) & (0.216) & (0.216) & (0.216) \\ 0.101 & 0.061 & 0.107 & 0.069 & 0.069 & 0.07 & 0.392 & 0.226 & 0.454 & 0.284 & 0.268 & 0.269 \\ (0.191) & (0.224) & (0.190) & (0.223) & (0.223) & (0.223) & (0.341) & (0.400) & (0.340) & (0.398) & (0.398) & (0.398) \\ & & & & & & & & & & 1693 & \end{array}$

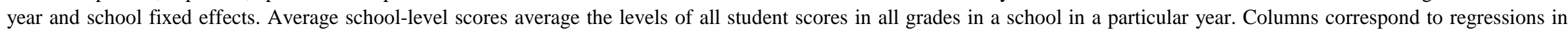
Table 4. Standard errors are clustered by school. 
Appendix Table A-2

Effect of new principals on school-level inputs and outcomes with linear time trends

\begin{tabular}{|c|c|c|c|c|c|c|c|c|c|c|c|c|}
\hline & $\begin{array}{c}\text { \% AYP } \\
\text { target met } \\
(1) \\
\end{array}$ & $\begin{array}{c}\text { Crime } \\
(2) \\
\end{array}$ & $\begin{array}{c}\text { Long-term } \\
\text { suspensions } \\
\text { (3) }\end{array}$ & $\begin{array}{c}\text { Daily } \\
\text { attendance } \\
(\%) \\
(4) \\
\end{array}$ & $\begin{array}{l}\text { Teachers } \\
\text { with } \\
\text { advanced } \\
\text { degree (\%) } \\
\text { (5) }\end{array}$ & $\begin{array}{c}\text { Teacher } \\
\text { turnover } \\
\text { rate }(\%) \\
(6) \\
\end{array}$ & $\begin{array}{c}\text { Licensed } \\
\text { teachers } \\
(\%) \\
(7) \\
\end{array}$ & $\begin{array}{c}\text { Board } \\
\text { Certified } \\
\text { teachers } \\
(\%) \\
(8)\end{array}$ & $\begin{array}{c}\% \text { Classes } \\
\text { w/ highly } \\
\text { qualified } \\
\text { teachers } \\
(9)\end{array}$ & $\begin{array}{c}\% \text { Teachers } \\
0-3 \text { yrs } \\
\text { experience } \\
(10) \\
\end{array}$ & $\begin{array}{c}\% \text { Teachers } \\
4-10 \text { yrs } \\
\text { experience } \\
(11) \\
\end{array}$ & $\begin{array}{c}\% \text { Teachers } \\
11+\text { yrs } \\
\text { experience } \\
(12) \\
\end{array}$ \\
\hline \multicolumn{13}{|l|}{ Panel A: One year } \\
\hline Lower value added & $\begin{array}{l}-0.011 \\
(0.017)\end{array}$ & $\begin{array}{c}0.022 \\
(0.067)\end{array}$ & $\begin{array}{l}-0.068 \\
(0.056)\end{array}$ & $\begin{array}{l}-0.001 \\
(0.001)\end{array}$ & $\begin{array}{c}0.005 \\
(0.006)\end{array}$ & $\begin{array}{c}0.015 \\
(0.010)\end{array}$ & $\begin{array}{c}0.010 \\
(0.006)\end{array}$ & $\begin{array}{l}-0.001 \\
(0.004)\end{array}$ & $\begin{array}{c}0.006 \\
(0.006)\end{array}$ & $\begin{array}{c}0.005 \\
(0.009)\end{array}$ & $\begin{array}{c}0.003 \\
(0.008)\end{array}$ & $\begin{array}{l}-0.008 \\
(0.006)\end{array}$ \\
\hline Similar value added & $\begin{array}{l}-0.017 \\
(0.020)\end{array}$ & $\begin{array}{c}0.045 \\
(0.087)\end{array}$ & $\begin{array}{l}-0.098 \\
(0.182)\end{array}$ & $\begin{array}{c}0.000 \\
(0.001)\end{array}$ & $\begin{array}{c}0.015 * * \\
(0.006)\end{array}$ & $\begin{array}{c}0.003 \\
(0.011)\end{array}$ & $\begin{array}{l}-0.009 \\
(0.006)\end{array}$ & $\begin{array}{c}0.006 \\
(0.004)\end{array}$ & $\begin{array}{c}0.002 \\
(0.008)\end{array}$ & $\begin{array}{l}-0.005 \\
(0.008)\end{array}$ & $\begin{array}{c}0.008 \\
(0.007)\end{array}$ & $\begin{array}{l}-0.003 \\
(0.008)\end{array}$ \\
\hline Higher value added & $\begin{array}{c}0.016 \\
(0.025)\end{array}$ & $\begin{array}{l}-0.009 \\
(0.098)\end{array}$ & $\begin{array}{l}-0.311 \\
(0.396)\end{array}$ & $\begin{array}{c}-0.001 \\
(0.001)\end{array}$ & $\begin{array}{l}-0.007 \\
(0.006)\end{array}$ & $\begin{array}{c}0.006 \\
(0.011)\end{array}$ & $\begin{array}{l}-0.010 * \\
(0.006)\end{array}$ & $\begin{array}{l}-0.006 \\
(0.005)\end{array}$ & $\begin{array}{l}-0.002 \\
(0.009)\end{array}$ & $\begin{array}{c}0.010 \\
(0.008)\end{array}$ & $\begin{array}{l}-0.001 \\
(0.007)\end{array}$ & $\begin{array}{l}-0.008 \\
(0.008)\end{array}$ \\
\hline First observation in data & $\begin{array}{c}-0.007 * \\
(0.004)\end{array}$ & $\begin{array}{c}0.037 \\
(0.026)\end{array}$ & $\begin{array}{l}-0.002 \\
(0.028)\end{array}$ & $\begin{array}{c}0.000 \\
(0.000)\end{array}$ & $\begin{array}{c}0.000 \\
(0.002)\end{array}$ & $\begin{array}{c}0.009 * * * \\
(0.003)\end{array}$ & $\begin{array}{c}0.001 \\
(0.002)\end{array}$ & $\begin{array}{l}-0.001 \\
(0.001)\end{array}$ & $\begin{array}{c}0.002 \\
(0.002)\end{array}$ & $\begin{array}{c}0.001 \\
(0.002)\end{array}$ & $\begin{array}{c}-0.001 \\
(0.002)\end{array}$ & $\begin{array}{c}0.001 \\
(0.002)\end{array}$ \\
\hline \multicolumn{13}{|l|}{ Panel B: Three year } \\
\hline Lower value added & $\begin{array}{l}-0.008 \\
(0.018)\end{array}$ & $\begin{array}{l}-0.026 \\
(0.087)\end{array}$ & $\begin{array}{c}0.039 \\
(0.093)\end{array}$ & $\begin{array}{l}-0.001 \\
(0.001)\end{array}$ & $\begin{array}{c}0.003 \\
(0.006)\end{array}$ & $\begin{array}{c}0.007 \\
(0.011)\end{array}$ & $\begin{array}{c}0.008 \\
(0.007)\end{array}$ & $\begin{array}{c}0.000 \\
(0.005)\end{array}$ & $\begin{array}{c}0.007 \\
(0.009)\end{array}$ & $\begin{array}{l}-0.002 \\
(0.008)\end{array}$ & $\begin{array}{c}0.006 \\
(0.007)\end{array}$ & $\begin{array}{l}-0.003 \\
(0.007)\end{array}$ \\
\hline Similar value added & $\begin{array}{c}0.005 \\
(0.021)\end{array}$ & $\begin{array}{c}0.038 \\
(0.102)\end{array}$ & $\begin{array}{c}0.120 \\
(0.124)\end{array}$ & $\begin{array}{c}0.001 \\
(0.001)\end{array}$ & $\begin{array}{c}0.006 \\
(0.006)\end{array}$ & $\begin{array}{c}0.005 \\
(0.013)\end{array}$ & $\begin{array}{c}0.000 \\
(0.007)\end{array}$ & $\begin{array}{c}0.001 \\
(0.004)\end{array}$ & $\begin{array}{l}-0.004 \\
(0.010)\end{array}$ & $\begin{array}{l}-0.005 \\
(0.007)\end{array}$ & $\begin{array}{c}0.006 \\
(0.008)\end{array}$ & $\begin{array}{l}-0.001 \\
(0.008)\end{array}$ \\
\hline Higher value added & $\begin{array}{c}0.033 \\
(0.022)\end{array}$ & $\begin{array}{l}-0.070 \\
(0.115)\end{array}$ & $\begin{array}{l}-0.222 \\
(0.355)\end{array}$ & $\begin{array}{l}-0.001 \\
(0.001)\end{array}$ & $\begin{array}{l}-0.008 \\
(0.007)\end{array}$ & $\begin{array}{c}0.007 \\
(0.013)\end{array}$ & $\begin{array}{l}-0.002 \\
(0.008)\end{array}$ & $\begin{array}{l}-0.001 \\
(0.004)\end{array}$ & $\begin{array}{c}0.003 \\
(0.009)\end{array}$ & $\begin{array}{c}0.007 \\
(0.009)\end{array}$ & $\begin{array}{l}-0.002 \\
(0.007)\end{array}$ & $\begin{array}{l}-0.004 \\
(0.007)\end{array}$ \\
\hline First observation in data & $\begin{array}{c}-0.015^{* * *} \\
(0.005)\end{array}$ & $\begin{array}{c}0.027 \\
(0.032)\end{array}$ & $\begin{array}{c}0.041 \\
(0.046)\end{array}$ & $\begin{array}{l}-0.001^{*} \\
(0.000)\end{array}$ & $\begin{array}{l}-0.002 \\
(0.002)\end{array}$ & $\begin{array}{c}0.011^{* * *} \\
(0.004)\end{array}$ & $\begin{array}{c}0.003 \\
(0.002)\end{array}$ & $\begin{array}{l}-0.002 \\
(0.002)\end{array}$ & $\begin{array}{c}0.008 * * * \\
(0.003)\end{array}$ & $\begin{array}{c}0.004 \\
(0.003)\end{array}$ & $\begin{array}{l}-0.001 \\
(0.003)\end{array}$ & $\begin{array}{l}-0.003 \\
(0.003)\end{array}$ \\
\hline Mean value of dep. variable & 0.931 & 0.419 & 0.240 & 0.951 & 0.258 & 0.169 & 0.934 & 0.119 & 0.949 & 0.228 & 0.289 & 0.483 \\
\hline Number of observations & 8,545 & 8,545 & 6,717 & 9,936 & 9,936 & 9,936 & 9,936 & 8,477 & 8,545 & 9,936 & 9,936 & 9,936 \\
\hline
\end{tabular}

